\title{
DIVERSITY OF MULTINUCLEATE RHIZOCTONIA SPP. IN SOIL OF TWO FOREST NURSERIES GARNCARSKIBRÓD AND LIPKA
}

\author{
Marta Bełka ${ }^{凶}$, Małgorzata Mańka \\ Department of Forest Phytopathology, Poznań University of Life Sciences \\ Wojska Polskiego 71C, 60-628 Poznań, Poland
}

\begin{abstract}
Damping-off disease is the most important of all diseases in forest nurseries with the most common pathogens causing the disease in forest nurseries worldwide include species from genera: Fusarium, Rhizoctonia, Phytophthora, Pythium. In the study two forest nurseries were screened for multinucleate Rhizoctonia isolates. Of all the soil samples collected, 132 isolates classified as Rhizoctonia were obtained, 89 isolates from Garncarskibród forest nursery and 43 from Lipka. All the isolates were multinucleate, that is representing $R$. solani anamorph. Isolates belonged to seven different anastomosis groups. In Lipka AG-5, AG1-IC, AG2-1, and AG2-2 were present while the diversity of AGs was greater in Grancarskibród, where AG1-IB, AG1-IC, AG2-1, AG2-2, AG2-3 and AG4-HG2 were isolated.
\end{abstract}

Keywords: Rhizoctonia solani, anastomosis group, forest nursery, damping-off

\section{INTRODUCTION}

Trees both in forest nurseries and in natural habitats are at risk of attacks by various pathogens (Hietala et al., 2005; Mańka, 2005; Sierota, 1998). Damping-off disease is the most common and the most important of all diseases at an early stage of their lives, the more frequently occurring, the longer a nursery is being operated, which is associated with accumulation of inoculum in soil (Hietala et al., 2005; Mańka, 2005). The most common pathogens causing damping-off in forest nurseries worldwide include species from genera: Fusarium, Rhizoctonia, Phytophthora, Pythium (Huang and Kuhlman, 1990; Lilja et al., 1995; 2010; Mohanan et al., 2005; Orlikowski and Oszako, 2009; Perrin and Sampagni, 1986; Sutherland and Davies, 1991; Vaartaja and Cram, 1956).

Fungi belonging to the Rhizoctonia genus represent a wide range of pathogenic, non-pathogenic and mutualistic species (Cubeta et al., 1995). Most studies on this group of fungi focus on agricultural plants, and only few of them were conducted in forest nurseries (Hietala and Sen, 1996).

Until recently, classifying an organism into the Rhizoctonia genus was based on biochemical, ecological and morphological criteria as well as the ability of an individual isolate to anastomosing with known testers. The later use of molecular techniques in phytopathology resulted in a serious rearrangement within the Rhizctonia genus (Sneh et al., 1998; 2008).

Species classified as Rhizoctonia spp. are a collection of fungi, in which the differences relate to the stage of anamorph, teleomorph, size and shape of sclerotia, number of nuclei per cell and colour of the mycelium (Sneh et al., 1998; Tu and Kimbrough, 1975). Rhizoctonia solani is the best-known plant pathogen within the genus of Rhizoctonia. In 1929 Wiant was the first to associate the occurrence of

$\square_{\text {marta.belka@up.poznan.pl }}$ 
conifer seedlings damping-off with $R$. solani. Within the species $R$. solani (and other Rhizoctonia spp.) there are numerous anastomosis groups (AG) which are of great importance from the point of view of pathogenicity to plants. The share of various AGs in Rhizoctonia population in soil may affect the disease threat of plants.

\section{MATERIAL AND METHODS}

Soil samples were harvested from the top $15 \mathrm{~cm}$ of the soil profile from nurseries of Forest Districts Lipka and Oborniki (Fig. 1). The soil was collected in early spring, before any chemicals were used. Samples were placed in sterile cotton bags and proceeded immediately after reaching the laboratory.

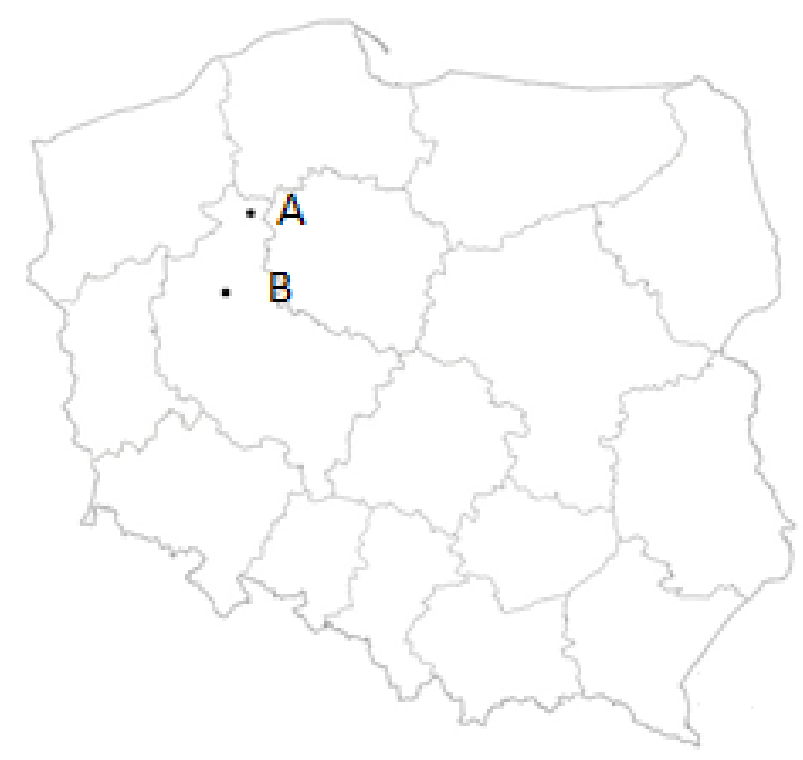

Fig. 1. Location of forest nurseries Lipka (A) and Garncarskibród (B) in Poland (R. Witkowski)

Rys. 1. Lokalizacja szkółek leśnych Lipka (A) i Garncarskibród (B) w Polsce (R. Witkowski)

Rhizoctonia isolates were obtained from soil samples using two trapping methods. The first method was based on the use of wooden toothpicks (Paulitz and Schroeder, 2005; modified). Toothpicks (10 per $700 \mathrm{ml}$ of soil in pot) were inserted into the soil to a depth of
$5 \mathrm{~cm}$, evenly spaced in the pot. After 48 hours, toothpicks were removed and placed on Petri plates with PDA, supplemented with antibiotics (Streptomycin $0.1 \mathrm{~g} / 1$ and Penicillin-G sodium salt $0.1 \mathrm{~g} / \mathrm{l}$ ). The plates with two toothpicks per plate were incubated for 24 hours at room temperature. All mycelia growing from toothpicks were transferred onto potato dextrose agar (PDA) plates to identify Rhizoctonia isolates.

In the second method pine seeds, which were sown ( 25 seeds per pot) to a volume of $700 \mathrm{ml}$ of unified soil from a nursery, were used. Then, after emergence of the first seedlings observation was carried out to capture the very first symptoms of damping-off (Fig. 2). The symptomatic seedlings were disinfected with $0.5 \%$ sodium hypochlorite for 5 minutes, $70 \%$ ethanol $(1 \mathrm{~min})$ and washed three times in distilled sterilized water, for five minutes jointly. Next, the symptomatic parts of seedlings were transferred onto PDA, supplemented with antibiotics (Streptomycin $0.1 \mathrm{~g} / 1$ and Penicillin-G sodium salt $0.1 \mathrm{~g} / \mathrm{l}$ ) to prevent the growth of bacteria. All isolates growing out of the inocula were transferred onto PDA.

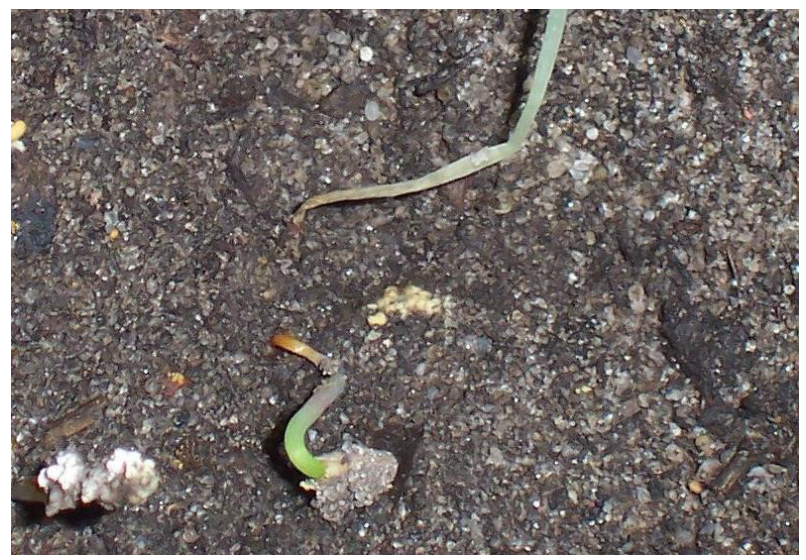

Fig. 2. Pinus sylvestris seedlings with damping-off symptoms (Photo M. Bełka)

Rys. 2. Siewki Pinus sylvestris z objawami zgorzeli siewek (fot. M. Bełka)

The number of nuclei in the cells of obtained $R h i$ zoctonia isolates was determined with the method described by Bandoni (1979) The average number of nuclei was calculated for 50 cells of each isolate (Table 1). 
Bełka, M., Mańka, M. (2017). Diversity of multinucleate Rhizoctonia spp. in soil of two forest nurseries Garncarskibród and Lipka. Acta Sci. Pol. Silv. Colendar. Ratio Ind. Lignar., 16(4), 233-242. http://dx.doi.org/10.17306/J.AFW.2017.4.24

Table 1. Mean values and standard deviations of the average number of nuclei in a cell

Tabela 1. Wartości średnie oraz odchylenia standardowe średniej liczby jąder w komórce

\begin{tabular}{|c|c|c|c|c|}
\hline \multirow{2}{*}{$\begin{array}{l}\text { Anastomosis } \\
\text { group } \\
\text { Grupa } \\
\text { anastomozowa }\end{array}$} & \multicolumn{2}{|r|}{ Lipka } & \multicolumn{2}{|r|}{ Garncarskibród } \\
\hline & $\begin{array}{l}\text { mean } \\
\text { średnia }\end{array}$ & $\begin{array}{c}\text { standard deviation } \\
\text { odchylenie standardowe }\end{array}$ & $\begin{array}{l}\text { mean } \\
\text { średnia }\end{array}$ & $\begin{array}{c}\text { standard deviation } \\
\text { odchylenie standardowe }\end{array}$ \\
\hline AG-5 & 11.917 & 2.341 & & \\
\hline AG1-IB & & & 10.362 & 2.063 \\
\hline AG1-IC & 10.702 & 2.336 & 10.885 & 2.977 \\
\hline AG2-1 & 13.440 & 2.421 & 9.850 & 0.952 \\
\hline AG2-2 & 10.625 & 0.946 & 11.409 & 0.750 \\
\hline AG2-3 & & & 7.304 & 2.272 \\
\hline AG4-HG2 & & & 9.153 & 1.078 \\
\hline $\mathrm{NIR}_{0.05}$ & 2.3 & & 2.91 & \\
\hline$P>F$ & $<0.001$ & & $<0.001$ & \\
\hline
\end{tabular}

One-factor analysis of variance was conducted for both nurseries.

Jednoczynnikowa analiza wariancji została przeprowadzona dla obu szkółek.

To isolate DNA, isolates were grown on liquid broth for 7 days. After that time, the mycelium was placed on sterile filter paper and the excessive medium was removed. The dried mycelium was put into Eppendorf tubes $(1.2 \mathrm{ml})$, and mashed with sterile metal rods. DNA extraction was carried out using a DNeasy Plant Mini Kit (Qiagen) according to manufacturer's recommendations. Isolates obtained in the study have been first separated based on the number of nuclei per cell. To assign isolates to the anastomosis subgroups the restriction enzymes digestion of RFLP of rDNA-ITS regions was performed. Primers ITS4 (TCCTCCGCTTATTGATATGC) and ITS5 (GGAAGTAAAAGTCGTAACAAGG) were used for amplification of the nuclear rDNA-ITS region (White et al., 1990). The PCR amplification reactions were conducted with PCR Mix (A\&A Biotechnology). The denaturation step at $94^{\circ} \mathrm{C}$ for $10 \mathrm{~min}$ was followed by 35 cycles of $1 \mathrm{~min}$ at $94^{\circ} \mathrm{C}, 1 \mathrm{~min}$ at $60^{\circ} \mathrm{C}$ and $1 \mathrm{~min}$ at $72^{\circ} \mathrm{C}$. Cycling ended with a final extension step at $72^{\circ} \mathrm{C}$ for $10 \mathrm{~min}$ (Biometra, T-Gradient Thermoblock). After the DNA extraction and restriction enzymes digestion of RFLP of rDNA-ITS regions the results of electrophoresis were checked under the UV light, and the resulting patterns were compared with those presented in the work of Guillemaut et al. (2003). Four restriction enzymes (MseI, AvaII, HincII, and MunI) were used in the study to assign isolates to a certain anastomosis group (AG; Table 2), it has also been verified by comparing the ITS-rDNA sequences of all isolates with sequences deposited in GenBank (http:// www.ncbi.nlm. nih.gov/GenBank). Sequencing of ITS-rDNA region was done by an outside company.

\section{RESULTS}

Of all the soil samples collected from the surveyed nurseries 132 isolates classified as Rhizoctonia were obtained, 89 isolates from Garncarskibród forest nursery and 43 from Lipka. All the isolates were multinucleate, that is representing $R$. solani anamorph. Isolates belonged to seven different anastomosis groups. In Lipka AG-5, AG1-IC, AG2-1, and AG2-2 were present while the diversity of AGs was greater in Grancarskibród, where AG1-IB, AG1-IC, AG2-1, AG2-2, AG2-3 and AG4-HG2 were isolated.

The lowest average number of nuclei was observed in AG2-3 isolates obtained from Garncarskibród 
Betka, M., Mańka, M. (2017). Diversity of multinucleate Rhizoctonia spp. in soil of two forest nurseries Garncarskibród and Lipka. Acta Sci. Pol. Silv. Colendar. Ratio Ind. Lignar., 16(4), 233-242. http://dx.doi.org/10.17306/J.AFW.2017.4.24

Table 2. Assignment of Rhizoctonia isolates to anastomosis groups and their percentage similarity with isolates deposited in GenBank

Tabela 2. Przynależność izolatów do poszczególnych grup anastomozowych i procent ich podobieństwa do izolatów zdeponowanych w GenBank

\begin{tabular}{|c|c|c|c|c|c|}
\hline $\begin{array}{l}\text { Isolate's code } \\
\text { Kod izolatu }\end{array}$ & $\begin{array}{l}\text { Anamorph } \\
\text { Anamorfa }\end{array}$ & $\begin{array}{l}\text { Anastomosis group } \\
\text { Grupa anastomozowa }\end{array}$ & $\begin{array}{l}\text { Teleomorph } \\
\text { Teleomorfa }\end{array}$ & $\begin{array}{c}\text { GenBank accession } \\
\text { number } \\
\text { Kod dostępu } \\
\text { w bazie GenBank }\end{array}$ & $\begin{array}{l}\text { Percentage of identity } \\
\text { Procent podobieństwa }\end{array}$ \\
\hline 1 & 2 & 3 & 4 & 5 & 6 \\
\hline \multicolumn{6}{|c|}{ Garncarskibród } \\
\hline MB110460 & R. solani & AG1-IC & T. cucumeris & AY881008.1 & 99 \\
\hline MB110424 & R. solani & AG1-IC & T. cucumeris & AY881008.1 & 99 \\
\hline MB110511 & R. solani & AG1-IC & T. cucumeris & AB122141.1 & 99 \\
\hline MB110508 & R. solani & AG1-IC & T. cucumeris & AB122141.1 & 99 \\
\hline MB110534 & R. solani & AG1-IC & T. cucumeris & AB122141.1 & 99 \\
\hline MB110649 & R. solani & AG1-IC & T. cucumeris & AB122141.1 & 99 \\
\hline MB110629 & R. solani & AG1-IC & T. cucumeris & AY154300.1 & 99 \\
\hline MB110672 & R. solani & AG1-IC & T. cucumeris & EU591808.1 & 99 \\
\hline MB110684 & R. solani & AG1-IC & T. cucumeris & EU591808.1 & 99 \\
\hline MB110627 & R. solani & AG1-IC & T. cucumeris & AY154300.1 & 99 \\
\hline MB110743 & R. solani & AG1-IC & T. cucumeris & AB122141.1 & 99 \\
\hline MB110758 & R. solani & AG1-IC & T. cucumeris & AB122141.1 & 99 \\
\hline MB110764 & R. solani & AG1-IC & T. cucumeris & AB122141.1 & 99 \\
\hline MB110766 & R. solani & AG1-IC & T. cucumeris & AY881008.1 & 99 \\
\hline MB110772 & R. solani & AG1-IC & T. cucumeris & AY 154300.1 & 99 \\
\hline MB110784 & R. solani & AG1-IC & T. cucumeris & AY881008.1 & 99 \\
\hline MB110799 & R. solani & AG1-IC & T. cucumeris & AY881008.1 & 99 \\
\hline MB110802 & R. solani & AG1-IC & T. cucumeris & AY154300.1 & 99 \\
\hline MB110823 & R. solani & AG1-IC & T. cucumeris & AY154300.1 & 99 \\
\hline MB110844 & R. solani & AG1-IC & T. cucumeris & AY154300.1 & 99 \\
\hline MB110913 & R. solani & AG1-IC & T. cucumeris & FJ746943.1 & 99 \\
\hline MB110923 & R. solani & AG1-IC & T. cucumeris & FJ746943.1 & 99 \\
\hline MB110940 & R. solani & AG1-IC & T. cucumeris & FJ746943.1 & 99 \\
\hline MB110402 & R. solani & AG1-IB & T. cucumeris & EU730824.1 & 99 \\
\hline MB110429 & R. solani & AG1-IB & T. cucumeris & EU730824.1 & 99 \\
\hline MB110517 & R. solani & AG1-IB & T. cucumeris & AB122138.1 & 99 \\
\hline MB110589 & R. solani & AG1-IB & T. cucumeris & AB122137.1 & 99 \\
\hline MB110612 & R. solani & AG1-IB & T. cucumeris & AB122137.1 & 99 \\
\hline MB110607 & R. solani & AG1-IB & T. cucumeris & FJ440191.1 & 99 \\
\hline MB110613 & R. solani & AG1-IB & T. cucumeris & FJ440191.1 & 99 \\
\hline MB110604 & R. solani & AG1-IB & T. cucumeris & GU596491.1 & 99 \\
\hline MB110605 & R. solani & AG1-IB & T. cucumeris & HQ185364.1 & 99 \\
\hline
\end{tabular}


Bełka, M., Mańka, M. (2017). Diversity of multinucleate Rhizoctonia spp. in soil of two forest nurseries Garncarskibród and Lipka. Acta Sci. Pol. Silv. Colendar. Ratio Ind. Lignar., 16(4), 233-242. http://dx.doi.org/10.17306/J.AFW.2017.4.24

Table 2 - cont. $\$ Tabela 2 - cd.

\begin{tabular}{|c|c|c|c|c|c|}
\hline 1 & 2 & 3 & 4 & 5 & 6 \\
\hline MB110630 & R. solani & AG1-IB & T. cucumeris & HQ185364.1 & 99 \\
\hline MB110624 & R. solani & AG1-IB & T. cucumeris & FJ435105.1 & 100 \\
\hline MB110628 & R. solani & AG1-IB & T. cucumeris & HQ185364.1 & 99 \\
\hline MB110711 & R. solani & AG1-IB & T. cucumeris & AB122137.1 & 99 \\
\hline MB110707 & R. solani & AG1-IB & T. cucumeris & FJ435105.1 & 100 \\
\hline MB110718 & R. solani & AG1-IB & T. cucumeris & AB122137.1 & 99 \\
\hline MB110744 & R. solani & AG1-IB & T. cucumeris & FJ435105.1 & 100 \\
\hline MB110817 & R. solani & AG1-IB & T. cucumeris & GU585667.1 & 99 \\
\hline MB110809 & R. solani & AG1-IB & T. cucumeris & FJ440191.1 & 99 \\
\hline MB110811 & R. solani & AG1-IB & T. cucumeris & HQ185364.1 & 99 \\
\hline MB110807 & R. solani & AG1-IB & T. cucumeris & GU596491.1 & 99 \\
\hline MB110810 & R. solani & AG1-IB & T. cucumeris & EU730824.1 & 99 \\
\hline MB110914 & R. solani & AG1-IB & T. cucumeris & AB122137.1 & 99 \\
\hline MB110905 & R. solani & AG1-IB & T. cucumeris & EU730824.1 & 99 \\
\hline MB110917 & R. solani & AG1-IB & T. cucumeris & FJ435105.1 & 100 \\
\hline MB110908 & R. solani & AG1-IB & T. cucumeris & FJ435105.1 & 100 \\
\hline MB110904 & R. solani & AG1-IB & T. cucumeris & FJ435105.1 & 100 \\
\hline MB110911 & R. solani & AG1-IB & T. cucumeris & FJ435105.1 & 100 \\
\hline MB110910 & R. solani & AG1-IB & T. cucumeris & EU730824.1 & 99 \\
\hline MB110411 & R. solani & AG2-2 & T. cucumeris & AB054856.1 & 99 \\
\hline MB110407 & R. solani & AG2-2 & T. cucumeris & AB054856.1 & 99 \\
\hline MB110404 & R. solani & AG2-2 & T. cucumeris & FJ492165.3 & 99 \\
\hline MB110603 & R. solani & AG2-2 & T. cucumeris & FJ492123.3 & 99 \\
\hline MB110710 & R. solani & AG2-2 & T. cucumeris & AB054856.1 & 99 \\
\hline MB110708 & R. solani & AG2-2 & T. cucumeris & FJ492165.3 & 99 \\
\hline MB110801 & R. solani & AG2-2 & T. cucumeris & FJ492123.3 & 99 \\
\hline MB110907 & R. solani & AG2-2 & T. cucumeris & FJ492123.3 & 99 \\
\hline MB110918 & R. solani & AG2-2 & T. cucumeris & FJ492123.3 & 99 \\
\hline MB110403 & R. solani & AG2-1 & T. cucumeris & JF792354.1 & 99 \\
\hline MB110611 & R. solani & AG2-1 & T. cucumeris & AB054853.1 & 99 \\
\hline MB110608 & R. solani & AG2-1 & T. cucumeris & JF792354.1 & 99 \\
\hline MB110614 & R. solani & AG2-1 & T. cucumeris & FJ492102.3 & 99 \\
\hline MB110414 & R. solani & AG2-3 & T. cucumeris & U57743.1 & 99 \\
\hline MB110440 & R. solani & AG2-3 & T. cucumeris & U57743.1 & 99 \\
\hline MB110502 & R. solani & AG2-3 & T. cucumeris & U57741.1 & 99 \\
\hline MB110516 & R. solani & AG2-3 & T. cucumeris & U57741.1 & 99 \\
\hline MB110640 & R. solani & AG2-3 & T. cucumeris & FJ435099.1 & 99 \\
\hline MB110623 & R. solani & AG2-3 & T. cucumeris & U57741.1 & 99 \\
\hline
\end{tabular}


Bełka, M., Mańka, M. (2017). Diversity of multinucleate Rhizoctonia spp. in soil of two forest nurseries Garncarskibród and Lipka. Acta Sci. Pol. Silv. Colendar. Ratio Ind. Lignar., 16(4), 233-242. http://dx.doi.org/10.17306/J.AFW.2017.4.24

Table 2 - cont. $\$ Tabela 2 - cd.

\begin{tabular}{|c|c|c|c|c|c|}
\hline 1 & 2 & 3 & 4 & 5 & 6 \\
\hline MB110622 & R. solani & AG2-3 & T. cucumeris & U57743.1 & 99 \\
\hline MB110618 & R. solani & AG2-3 & T. cucumeris & U57743.1 & 99 \\
\hline MB110601 & R. solani & AG2-3 & T. cucumeris & U57740.1 & 99 \\
\hline MB110720 & R. solani & AG2-3 & T. cucumeris & AY154312.1 & 99 \\
\hline MB110711 & R. solani & AG2-3 & T. cucumeris & AY154312.1 & 99 \\
\hline MB110702 & R. solani & AG2-3 & T. cucumeris & AY154312.1 & 99 \\
\hline MB110712 & R. solani & AG2-3 & T. cucumeris & AY154312.1 & 99 \\
\hline MB110709 & R. solani & AG2-3 & T. cucumeris & U57743.1 & 99 \\
\hline MB110721 & R. solani & AG2-3 & T. cucumeris & U57743.1 & 99 \\
\hline MB110704 & R. solani & AG2-3 & T. cucumeris & U57743.1 & 99 \\
\hline MB110804 & R. solani & AG2-3 & T. cucumeris & FJ435099.1 & 99 \\
\hline MB110806 & R. solani & AG2-3 & T. cucumeris & U57740.1 & 99 \\
\hline MB110815 & R. solani & AG2-3 & T. cucumeris & AY154312.1 & 99 \\
\hline MB110912 & R. solani & AG2-3 & T. cucumeris & AY154312.1 & 99 \\
\hline MB110929 & R. solani & AG2-3 & T. cucumeris & AY154312.1 & 99 \\
\hline MB110930 & R. solani & AG2-3 & T. cucumeris & AY154312.1 & 99 \\
\hline MB110819 & R. solani & AG4-HG2 & T. practicola & HQ629864.1 & 99 \\
\hline MB110820 & R. solani & AG4-HG2 & T. practicola & HQ629864.1 & 99 \\
\hline MB110808 & R. solani & AG4-HG2 & T. practicola & HQ629864.1 & 99 \\
\hline \multicolumn{6}{|c|}{ Lipka } \\
\hline MB120411 & R. solani & AG1-IC & T. cucumeris & FJ435098.1 & 99 \\
\hline MB120434 & R. solani & AG1-IC & T. cucumeris & FJ435098.1 & 99 \\
\hline MB120574 & R. solani & AG1-IC & T. cucumeris & FJ435106.1 & 99 \\
\hline MB120518 & R. solani & AG1-IC & T. cucumeris & HQ185375.1 & 99 \\
\hline MB120519 & R. solani & AG1-IC & T. cucumeris & FJ435098.1 & 99 \\
\hline MB120501 & R. solani & AG1-IC & T. cucumeris & HQ185375.1 & 99 \\
\hline MB120513 & R. solani & AG1-IC & T. cucumeris & FJ746943.1 & 99 \\
\hline MB120529 & R. solani & AG1-IC & T. cucumeris & FJ746943.1 & 99 \\
\hline MB120551 & R. solani & AG1-IC & T. cucumeris & EU591808.1 & 99 \\
\hline MB120516 & R. solani & AG1-IC & T. cucumeris & EU591808.1 & 99 \\
\hline MB120604 & R. solani & AG1-IC & T. cucumeris & AB122141.1 & 99 \\
\hline MB120605 & R. solani & AG1-IC & T. cucumeris & FJ435106.1 & 99 \\
\hline MB120612 & R. solani & AG1-IC & T. cucumeris & HQ185375.1 & 99 \\
\hline MB120727 & R. solani & AG1-IC & T. cucumeris & FJ435098.1 & 99 \\
\hline MB120712 & R. solani & AG1-IC & T. cucumeris & FJ435098.1 & 99 \\
\hline MB120702 & R. solani & AG1-IC & T. cucumeris & FJ746943.1 & 99 \\
\hline MB120708 & R. solani & AG1-IC & T. cucumeris & HQ185375.1 & 99 \\
\hline MB120714 & R. solani & AG1-IC & T. cucumeris & FJ435098.1 & 99 \\
\hline
\end{tabular}


Bełka, M., Mańka, M. (2017). Diversity of multinucleate Rhizoctonia spp. in soil of two forest nurseries Garncarskibród and Lipka. Acta Sci. Pol. Silv. Colendar. Ratio Ind. Lignar., 16(4), 233-242. http://dx.doi.org/10.17306/J.AFW.2017.4.24

Table 2 - cont. $\$ Tabela 2 - cd.

\begin{tabular}{|c|c|c|c|c|c|}
\hline 1 & 2 & 3 & 4 & 5 & 6 \\
\hline MB120813 & R. solani & AG1-IC & T. cucumeris & FJ435106.1 & 99 \\
\hline MB120904 & R. solani & AG1-IC & T. cucumeris & FJ435106.1 & 99 \\
\hline MB120546 & R. solani & AG-5 & T. cucumeris & AY586186.1 & 99 \\
\hline MB120528 & R. solani & AG-5 & T. cucumeris & AY586186.1 & 99 \\
\hline MB120503 & R. solani & AG-5 & T. cucumeris & AY586186.1 & 99 \\
\hline MB120640 & R. solani & AG-5 & T. cucumeris & AY586166.1 & 99 \\
\hline MB120637 & R. solani & AG-5 & T. cucumeris & AY586166.1 & 99 \\
\hline MB120764 & R. solani & AG-5 & T. cucumeris & AY586186.1 & 99 \\
\hline MB120753 & R. solani & AG-5 & T. cucumeris & AY586186.1 & 99 \\
\hline MB120728 & R. solani & AG-5 & T. cucumeris & HQ185377.1 & 99 \\
\hline MB120717 & R. solani & AG-5 & T. cucumeris & HQ185373.1 & 99 \\
\hline MB120749 & R. solani & AG-5 & T. cucumeris & HQ185373.1 & 99 \\
\hline MB120934 & R. solani & AG-5 & T. cucumeris & HQ185377.1 & 99 \\
\hline MB120948 & R. solani & AG-5 & T. cucumeris & AY586166.1 & 99 \\
\hline MB120939 & R. solani & AG-5 & T. cucumeris & EU244843.1 & 99 \\
\hline MB120954 & R. solani & AG-5 & T. cucumeris & HQ629863.1 & 99 \\
\hline MB120972 & R. solani & AG-5 & T. cucumeris & HQ629863.1 & 99 \\
\hline MB120511 & R. solani & AG2-2 & T. cucumeris & FJ492124.3 & 99 \\
\hline MB120504 & R. solani & AG2-2 & T. cucumeris & FJ492124.3 & 99 \\
\hline MB120803 & R. solani & AG2-2 & T. cucumeris & FJ492124.3 & 99 \\
\hline MB120912 & R. solani & AG2-2 & T. cucumeris & FJ492124.3 & 99 \\
\hline MB120817 & R. solani & AG2-1 & T. cucumeris & EU730857.1 & 99 \\
\hline MB120844 & R. solani & AG2-1 & T. cucumeris & EU730857.1 & 99 \\
\hline MB120819 & R. solani & AG2-1 & T. cucumeris & EU730857.1 & 99 \\
\hline MB120808 & R. solani & AG2-1 & T. cucumeris & EU730857.1 & 99 \\
\hline
\end{tabular}

(Table 1). The highest number of nuclei per cell was observed in AG2-1 isolates obtained from Lipka, with the average number of 13.44 nuclei per cell (AG2-1 isolates from Garncarskibród with the average of 9.85 nuclei per cell). The most common AG found in both nurseries, AG 1-IC, was characterized by the average number of 10.702 and 10.885 nuclei per cell Lipka and Garncarskibród, accordingly.

In Lipka forest nursery the biggest number of isolates belonged to AG1-IC (20 isolates), AG-5 (15 isolates), and 4 isolates of AG2-1 and AG2-2. In Garncarskibród the biggest number of isolates assigned to AG1IB (28 isolates) followed by AG1-IC (23 isolates), and
AG2-3 (22 isolates) were found. There were 9 isolates AG2-2, 4 isolates AG2-1 and three AG4-HG2 isolates obtained from Garncarskibród.

\section{DISCUSSION}

From among the 132 Rhizoctonia isolates obtained all represented $R$. solani, a species widely distributed in Polish forest nurseries. The lower number of isolates in Lipka forest nursery is also shown on the site, where damping-off is not as severe as in Garncarskibród.

The knowledge of the occurrence of Rhizoctonia anastomosis groups in forest nurseries is insufficient. 
Bełka, M., Mańka, M. (2017). Diversity of multinucleate Rhizoctonia spp. in soil of two forest nurseries Garncarskibród and Lipka. Acta Sci. Pol. Silv. Colendar. Ratio Ind. Lignar., 16(4), 233-242. http://dx.doi.org/10.17306/J.AFW.2017.4.24

As different anastomosis groups have different sensitivity to fungicides (Carling et al., 1999; Campion et al., 2003) and are characterized by different pathogenicity (Bełka and Mańka, 2014), the knowledge of their occurrence in soil could have a big impact on seedling protection approach. The results of some studies (Herr, 1995; Sharon et al., 2011) suggest the possibility of using non-pathogenic Rhizoctonia strains as biological control agents against those highly pathogenic ones. In their research Camporota and Perrin (1998) demonstrated the predominant role of $R$. solani as the primary pathogen causing dampingoff of pine seedlings. In Polish nurseries, so far only the research by Stępniewska-Jarosz et al. (2006), and Bełka and Mańka (2014) described the differences between anastomosis groups in Polish forest nurseries. Stępniewska-Jarosz et al. (2006) found five, and Bełka and Mańka (2014) isolated four different anastomosis groups from Polish forest nurseries soil. The research by Stępniewska-Jarosz et al. (2006) and Bełka and Mańka (2014) were partially conducted in the same area giving different results. In the later work (Bełka and Mańka, 2014) isolates AG4-HG2 were observed. The difference may have resulted from possible bridging of some isolates belonging to certain AGs with isolates belonging to the other (Ogoshi, 1972) or from the fact that different techniques were used to assign isolates to certain AGs. While Stępniewska-Jarosz et al. (2006) used classic techniques, with culture of isolates in vitro and subsequent observation of their growth under microscope, Bełka and Mańka (2014) based their study fully on molecular methods. As most of the research on Rhizoctonia not only in Poland, but worldwide has been conducted on agricultural plants, it is highly desirable to further screen forest nurseries for the pathogen and its anastomosis groups. Better recognition of the problem would help in saving considerable amounts of money spent on chemicals used for damping-off prevention and in approaching the principles of integrated pest management (IPM).

Many AGs and subgroups of $R$. solani and binucleate Rhizoctonia spp. have been reported as causal agents of Rhizoctonia diseases on a wide range of host species (Sneh et al., 2008). For example, AG1-IA possesses the ability to cause the disease in such plants as rice (Oryza sativa), corn (Zea mays), barley (Hordeum vulgare), potato (Solanum tuberosum), and many other agriculturally important species but cannot attack trees (Sneh et al., 2008). In contrast, Rhizoctonia species belonging to the same anastomosis group - AG1 subgroup IB cause diseases in Larix spp., Acacia spp., Eucalyptus spp., Pinus spp. and Cupressus spp. Not only pathogenicity of different anastomosis groups differs between species. The study carried out on uninucleate isolates confirmed that they were the causing agents of damping-off in many Finnish nurseries (Grönberg et al., 2006; Sen, 2001). At the same time from Norwegian and Finnish forest nurseries uninucleate and binucleate strains of Rhizoctonia have been isolated from healthy seedlings of Scots pine and Norway spruce (Hietala, 1995; Lilja et al., 1992; 1994).

In conclusion, more research on Rhizoctonia spp. in forest nurseries is needed. The knowledge of AGs present in soil and their pathogenicity would be helpful in choosing the right protection method.

\section{REFERENCES}

Bandoni, R. J. (1979). Safranin O as a rapid nuclear stain for fungi. Mycologia, 11(4), 873-874.

Bełka, M., Mańka, M. (2014). Characteristics and diversity of Rhizoctonia spp. population in soil of selected forest bare-root nurseries in Poland. Acta Mycol., 49(2), 279-290.

Campion, C., Chatot, C., Perratoon, B., Andrivon, D. (2003). Anastomosis groups, pathogenicity and sensitivity to fungicides of Rhizoctonia solani isolates collected on potato crops in France. Eur. J. Plant Pathol., 109, 983-992.

Camporota, P., Perrin, R. (1998). Characterization of Rhizoctonia species involved in tree seedling damping-off in French forest nurseries. Appl. Soil Ecol., 10, 65-71.

Carling, D. E., Pope, E. J., Brainard, K. A., Carter, D. A. (1999). Characterization of mycorrhizal isolates of Rhizoctonia solani from an orchid, including AG-12, a new anastomosis group. Ecol. Populat. Biol., 89(10), 942-946.

Cubeta, M. A., Vilgalys, R., Gonzales, D. (1995). Molecular approaches for examining species concepts in $R h i$ zoctonia. In: International Symposium on Rhizoctonia, ISR'95, Leeuwenhorst Congres Centrum. Noordwijkerhout, Netherlands, June 27-30, 1995.

Grönberg, H., Kaparakis, G., Sen, R. (2006). Binucleate Rhizoctonia (Ceratorhiza spp.) as non-mycorrhizal endophytes alter Pinus sylvestris L. seedling root architecture 
Bełka, M., Mańka, M. (2017). Diversity of multinucleate Rhizoctonia spp. in soil of two forest nurseries Garncarskibród and Lipka. Acta Sci. Pol. Silv. Colendar. Ratio Ind. Lignar., 16(4), 233-242. http://dx.doi.org/10.17306/J.AFW.2017.4.24

and affect growth of rooted cuttings. Scand. J. For. Res., 21, 450-457.

Guillemaut, C., Edel-Hermann, V., Camporota, P., Alabouvette, C., Richard-Molard, M., Steinberg, C. (2003). Typing of anastomosis groups of Rhizoctonia solani by restriction analysis of ribosomal DNA. Can. J. Microbiol., 49, 556-558.

Herr, L. J. (1995). Biological control of Rhizoctonia solani by binucleate Rhizoctonia spp. and hypovirulent $R$. solani agents. Crop Prot., 14, 179-186.

Hietala, A. M. (1995). Uni- and binucleate Rhizoctonia spp. co-existing on the roots of Norway spruce seedlings suffering from root dieback. Eur. J. For. Pathol., 25, 136-144.

Hietala, A. M., Mehli, L., Nagy, N. E., Kvaalen, H., La Porta, N. (2005). Rhizoctonia solani AG 2-1 as a causative agent of cotyledon rot on European beech (Fagus sylvatica). For. Pathol., 35, 397-410.

Hietala, A. M., Sen, R. (1996). Rhizoctonia associated with forest trees. In: B. Sneh, S. Jabaji-Hare, S. Neate, G. Dijst (Eds.), Rhizoctonia species: Taxonomy, molecular biology, ecology, pathology and disease control (pp. 351-358). Dordrecht: Kluwer Acad. Publ.

Huang, J. W., Kuhlman, E. G. (1990). Fungi associated with damping-off of Slash pine seedlings in Georgia. Plant Disease, 74, 27-30.

Lilja, A. (1994). The occurence and pathogenicity of uniand binucleate Rhizoctonia and Pythiaceae fungi among cornifer seedlings in Finnish forest nurseries. Eur. J. For. Pathol., 24, 181-192.

Lilja, A., Hallaksela, A.M., Heionen, R. (1995). Fungi colonizing Scots pine cones scales and seed and their pathogenicity. Eur. J. For. Pathol., 25, 38-46.

Lilja, A., Lilja, S., Poteri, M., Ziren, L. (1992). Conifer seedling root fungi and root dieback in Finnish nurseries. Scand. J. For. Res., 7, 547-556.

Lilja, A., Poteri, M., Petäistö, R.-L., Rikala, R., Kurkela, T., Kasanen, R. (2010). Fungal diseases in forest nurseries in Finland. Silva Fenn., 44(3), 525-545.

Mańka, K. (2005). Fitopatologia leśna [Forest phytopathology]. Warszawa: PWRiL [in Polish].

Mohanan, C., Retheesh, N., Nair, L. P., Rajesh Kumar, K. C. (2005). Disease problems in root trainer forest nurseries in Kerala State and their management. Working Papers of the Finnish Forest Research Institute 11.

Ogoshi, A. (1972). Grouping of Rhizoctonia solani Kuehn with hyphal anastomosis. Ann. Phytopathol. Soc. Japan, 38, 117-122.

Orlikowski, L., Oszako, T. (red., 2009). Fytoftorozy w szkółkach i drzewostanach leśnych: Klucz do oznaczania
Phytophthora: atlas fytoftoroz siewek i drzew leśnych [Phytophthora species in forest nurseries and forest stands: The key to Phytophthora: seedlings and forest trees phytophthorosis atlas]. Warszawa: Centr. Inform. LP [in Polish].

Paulitz, T. C., Schroeder, K. L. (2005). A new metod for the quantification of Rhizoctonia solani and R. oryzae from soil. Plant Disease, 89, 767-72.

Perrin, R., Sampagni, R. (1986). La fonte des semis en pepiniere forestiere. Eur. J. For. Pathol., 16, 309-321.

Sen, R. (2001). Multitrophic interactions between a Rhizoctonia sp. and mycorrhizal fungi affect Scots pine seedling performance in nursery soil. New Phytol., 152, 543-553.

Sharon, M., Freeman, S., Sneh, B. (2011). Assessment of resistance pathways induced in Arabidopsis thaliana by hypovirulent Rhizoctonia spp. isolates. Genet. Resist., 101(7), 828-838.

Sierota, Z. (1998). Choroby infekcyjne w szkółkach leśnych [Infectious diseases in forest nurseries]. In: Z. Sierota, M. Małecka (Eds.), Profilaktyka i terapia w szkółkach leśnych zagrożonych przez choroby infekcyjne. Materiały konferencji naukowo-technicznej, 24-25 III 1998. Warszawa-Sękocin (pp. 5-9). Warszawa: Inst. Bad. Leśn. [in Polish].

Sneh, B., Burpee, L., Ogoshi, A. (1998). Identification of Rhizoctonia species. USA: APS Press.

Sneh, B., Sharon, M., Kuninaga, S. (2008). Comprehensive classification of Rhizoctonia spp. using rDNA+ITS sequence analysis complemented by percent sequence similarity. In: $4^{\text {th }}$ International Symposium on Rhizoctonia, 20-22 August 2008. The International Society of Plant Pathology, Rhizoctonia Subject Matter Committee, Berlin, Germany.

Stępniewska, S., Mańka, M., Asiegbu, O. (2006). Studies on anastomosis groups of Rhizoctonia solani isolates causing disease in two forest nurseries in Poland. For. Pathol., 36, 97-109.

Sutherland, J. R., Davis, C. (1991). Diseases and insects in forest nurseries in Canada. In: J. R. Sutherland, S. G. Glover (Eds.), Proceedings of the first meeting of UFRO Working Party S2.07-09 Diseases and insects in forest nurseries (pp. 25-32). Victoria, British Columbia, Canada, August 23-30, 1990. Forestry Canada, Pacific and Yukon Region, Pacific Forestry Centre, BC-X-331.

Tu, C. C., Kimbrough, J. W. (1975). A modified soil-over culture method for inducing basidia in Thanatephorus cucumeris. Phytopathology, 65, 730-731. 
Vaartaja, O., Cram, W. H. (1956). Damping-off of conifers and of caragana in Saskatchewan. Phytopathology, 46, $505-507$

White, T. J., Bruns, T. D., Lee, S., Taylor, J. (1990). Amplification and direct sequencing of fungal ribosomal RNA for phylogenetics. In: M. A. Innis, D. H. Gelfland, J. J. Sninsky, T. J. White (Eds.), PCR protocols: A guide to methods and applications (pp. 315-322). San Diego: Academic Press.

Wiant, J. S. (1929). The Rhizoctonia damping-off of cornifers and its control by chemical treatment of the soil. New York State Agricultural Experiment Station - Cornell University 124.

\section{RÓŻNORODNOŚĆ WIELOJĄDROWYCH RHIZOCTONIA SPP. W GLEBIE DWÓCH SZKÓtEK LEŚNYCH GARNCARSKIBRÓD I LIPKA}

\section{ABSTRAKT}

Zgorzel siewek jest najpoważniejszą spośród wszystkich chorób występujących w szkółkach leśnych. Choroba ta występuje na siewkach drzew na całym świecie, a powodują ją między innymi patogeny z rodzajów: Fusarium, Rhizoctonia, Phytophthora i Pythium. W pracy przedstawiono wyniki badań przeprowadzonych w dwóch szkółkach leśnych przebadanych pod kątem izolatów wielojądrowych Rhizoctonia. Ze wszystkich zebranych próbek gleby uzyskano 132 izolaty sklasyfikowane jako Rhizoctonia, 89 izolatów ze szkółki leśnej Garncarskibród i 43 z Lipki. Izolaty należały do siedmiu różnych grup anastomozowych. W Lipce opisano grupy AG-5, AG1-IC, AG2-1 i AG2-2. Zróżnicowanie grup anastomozowych w szkółce leśnej Grancarskibród było większe - wyizolowano AG1-IB, AG1-IC, AG2-1, AG2-2, AG2-3 oraz AG4-HG2.

Słowa kluczowe: Rhizoctonia solani, grupa anastomozowe, szkółka leśna, zgorzel siewek 